\title{
Host Plants and Pictorial Key of Aphids (Hemiptera: Aphididae) on Food Crops in Bogor and Cianjur Districts, West Java Province
}

\author{
Purnama Hidayat $^{1^{*}}$, Siti Fathur Rahmah ${ }^{1}$, Yani Maharani ${ }^{2}$ \\ ${ }^{1}$ Department of Plant Protection, Faculty of Agriculture, IPB University, Bogor 16680, Indonesia \\ ${ }^{2}$ Department of Plant Pests and Diseases, Faculty of Agriculture, Padjadjaran University (UNPAD), Jatinangor 45363, \\ Indonesia \\ *Corresponding author. Email: phidayat@apps.ipb.ac.id
}

\begin{abstract}
A few numbers of commonly found aphid species on food crops such as Aphis gossypii and Myzus persicae are well studied, but little is known for other species. This study aimed to determine the species, host plants, and colony characteristics of aphids associated with food crops in Bogor and Cianjur districts. Aphids were collected from eight main food crops i.e. rice, corn, taro, cassava, soybean, peanut, sweet potato, and wheat. Nine aphid species were identified, namely A. gossypii, A. glycines, A. craccivora, Rhopalosiphum maidis, $R$. padi, Sitobion avenae, $M$. persicae, Hyteroneura setariae, and Tetraneura nigriabdominalis. Most of these collected aphid species were in the wingless form. Aphis gossypii was the most abundant aphid species found. The plants belong to Family Poaceae were the most frequently crops infested by aphids. The result of this study indicated that there were some aphid species associated with food crops in Bogor and Cianjur districts which would potentially become serious pests.
\end{abstract}

Keywords: Aphis, Hyteroneura, Myzus, Rhopalosiphum, Tetraneura

\section{INTRODUCTION}

Aphids are important pests that can cause serious damage to various food crops. The aphids are causing damages to the crop by probing its stylus on the leaves, branches, and stems resulted necrotic or dry tissues. Furthermore, some aphids are plant virus vectors [1]. This insect has a soft body, length is about $1.5-3.5 \mathrm{~mm}$ depending on its species [2]. Most of aphids in their colonies are wingless. The insect will have some individual with wings when the population in one of its colonies is very dense. The winged aphids serve to fly or move and form a new colony [3].

In general, taxonomical information of the plant pest in Indonesia is relatively limited, including aphids. Most of taxonomical related research of aphids in Indonesia was done by relatively a long time ago. Van der Goot [4] reported that there were 82 species of aphid species in Java Island. In 1991, Noordam [5] reported 56 aphid species from the subfamily Hormaphidinae. Meanwhile, in 1994, 33 aphid species of the subfamily Greenideinae were identified [6]. In 2004 Noordam [7] identified a total of 82 aphid species from the subfamily Aphidinae, Lachininae, Neophyllaphidinae, and Pemphiginae in Java.

Many aphid species do not cause severe direct damages, instead as virus vectors that cause indirect damages to the plants. The direct damage causes by aphids is in the range from $6 \%$ to $25 \%$, while the damage by the role of aphid as virus vector can reach more than $80 \%$ [8].
There are several cultivated food crops that are reported as the host plant of aphids, among others are rice (Oryza sativa), corn (Zea mays), sweet potato (Ipomoea batatas), cassava (Manihot Esculenta), soybeans (Glycine max), peanut (Arachis hypogaea), mung beans (Vigna radiata), taro (Colocasia esculenta) and wheat (Triticum spp.). Irsan [9] reported several aphid species found on Solanaceae in West Java. This research aimed to identify aphid species in food crops in Bogor and Cianjur. The availability of host plant information and the simple key identification of aphid in food crops in Bogor and Cianjur will be beneficial for the integrated pest management program. Crop protection practitioners can be easily determine existing species and host plants, so that damage can be minimized.

\subsection{Materials and Methods}

The study was conducted from April to September 2013. Observation of host plants and collection of aphids was held in 23 villages in 18 sub-districts in Bogor and Cianjur. Geographical position and altitude were recorded using GPS. Aphids was directly collected from the host plants. The number of winged and unwinged aphids in one colony was counted. Ants associated with the aphid colony were also collected and identified.

Microscope preparation of aphid samples was carried out following the procedure of Blackman and Eastop [2] 
with some modifications. The identification was conducted by observing the morphological character of the adults using the Olympus CX21FS1 microscope and camera DinoEye AM432U which was connected to a PC. The main characters used for identification were antenna, antenna tubercles, cornicle, cauda, setae and rhinaria existence. Identification was conducted at the Insect Biosystematics Laboratory, Department of Plant Protection, Bogor Agricultural University (IPB University) using AphID [10] and other published identification key i.e. Blackman and Eastop 2000; 2006, Noordam 2004. Images of aphid characters was used to construct a pictorial key of collected aphids.

\subsection{Our Contribution}

The results of this study contribute to the field of entomology and aphid integrated pest management. The provided pictorial key for species identification is very beneficial for students, researchers, farmers and practitioners of plant protection.

\subsection{Paper Structure}

The rest of the paper is organized as follows. Section 1 introduces aphids as important pest that acts as vector virus in many host plants but taxonomical information about pest in Indonesia is limited. Section 2 presents nine species of aphids and their host plants in Bogor and Cianjur Districts. Moreover, it also presents description and pictorial key of aphids. Ultimately, section 3 concludes the paper.

\section{RESULTS AND DISCUSSION}

\subsection{Host Plant}

There were nine species of aphid in eight food crops was collected from Bogor and Cianjur (Table 1). Five species, i.e. A. gossypii, A. glycines, A. craccivora, R. maidis, and $R$. padi were considered as common species on food crops. A. gosypii was found in three types of plants in different families, namely taro, corn, and peanut. $R$. maidis was also found in three plants in different families, namely corn, cassava, and peanut. Aphis glycines and A. craccivora were only found in one type of plant, i.e. soybean and peanut, respectively; whereas $R$. padi was found in three types of plants in one family namely corn, rice, and wheat. These results, regarding the host plant family is different from previous report by Noordam [7]. According to Noordam [7] $R$. maidis was found only in the family Poaceae, while in this research the aphid was found in the families of Poaceae, Euphorbiaceae, and Fabaceae. However, the family of plants that frequently hosted aphid colonies was Poaceae. Beside five common species of aphid, there were four species of aphid found during this study, i.e. S. avenae, $M$. persicae, $H$. setariae, and T. nigriabdominalis. Noordam [7] reported that $M$. persicae, $H$. setariae, and $T$. nigriabdominalis has been found in Indonesia, especially in Java. According to Blackman and Eastop [2], distribution of $S$. avenae are Europe, South Asia, Africa and the Americas.

Aphis gossypii was the aphid with the greatest number of individuals per colony found in several locations with varying altitudes. According to Pedigo and Rice [11] the symptoms of direct damage caused by the aphid are leaf curling, dwarfing, withering, and finally die. However, we did not find any symptoms of direct damage by the aphid during the survey.

Table 1 List of aphids and plant hosts in Bogor and Cianjur Districts

\begin{tabular}{|c|c|c|c|c|c|}
\hline \multirow{2}{*}{ No. } & \multirow{2}{*}{ Species } & \multirow{2}{*}{ Village/Sub-district/District } & \multirow{2}{*}{$\begin{array}{l}\text { Altitude } \\
\text { (m asl) }\end{array}$} & \multicolumn{2}{|c|}{ Host plants } \\
\hline & & & & Species $^{A}$ & Family \\
\hline \multirow[t]{4}{*}{1.} & Aphis craccivora & Kayu manis/Cibinong/Bogor & 177 & $\begin{array}{l}\text { Peanut, A. hypogaea } \\
\text { (121) }\end{array}$ & Fabaceae \\
\hline & & Cikarawang/Dramaga/Bogor & 185 & Peanut, A. hypogaea (5) & Fabaceae \\
\hline & & & 190 & $\begin{array}{l}\text { Peanut, A. hypogaea } \\
\text { (33) }\end{array}$ & Fabaceae \\
\hline & & Cinangka/Ciampea/Bogor & 262 & $\begin{array}{l}\text { Peanut, A. hypogaea } \\
\text { (80) }\end{array}$ & Fabaceae \\
\hline \multirow[t]{2}{*}{2} & Aphis glycines & Kampus IPB/Dramaga/Bogor & 221 & Soybean, G. $\max (15)$ & Fabaceae \\
\hline & & Sukaresmi/Megamendung/Bogor & 600 & Soybean, G. $\max (30)$ & Fabaceae \\
\hline
\end{tabular}


Table 1 (Continuation)

\begin{tabular}{|c|c|c|c|c|c|}
\hline 3. & Aphis gossypii & Cikarawang/Dramaga/Bogor & 185 & Peanut, A. hypogaea (1) & Fabaceae \\
\hline & & & & Corn, Z. mays (29) & Poaceae \\
\hline & & Rancabungur/Rancabungur/Bogor & 185 & Peanut, A. hypogaea $(1)$ & Fabaceae \\
\hline & & Situgede/Bogor Barat/Bogor & 194 & Taro, C. esculenta (167) & Araceae \\
\hline & & & 195 & Taro, C. esculanta (50) & Araceae \\
\hline & & & 195 & Corn, Z. mays (7) & Poaceae \\
\hline & & Balumbangjaya/Bogor Barat/Bogor & 200 & Taro, C. esculenta (15) & Araceae \\
\hline & & Cinangka/Cinangka/Bogor & 262 & Taro, C. esculenta (77) & Araceae \\
\hline & & Cinangneng/Tenjolaya/Bogor & 416 & Taro, C. esculenta (20) & Araceae \\
\hline & & Ciletuk/Megamendung/Bogor & 593 & Taro, C. esculenta (34) & Araceae \\
\hline & & Cinangneng/TenjolayaBogor & 633 & Taro, C. esculenta (50) & Araceae \\
\hline & & Pamijahan/Pamijahan/Bogor & 683 & Taro, C. esculenta (20) & Araceae \\
\hline & & Cijedil/Cugenang/Cianjur & 783 & Taro, C. esculenta (152) & Araceae \\
\hline & & Cipendawa/Cipanas/Cianjur & 1157 & Taro, C. esculenta (30) & Araceae \\
\hline 4. & $\begin{array}{l}\text { Hyteroneura } \\
\text { setariae }\end{array}$ & Ciherang/Pacet/Cianjur & 783 & Corn, Z. mays (1) & Poaceae \\
\hline 5. & Myzus persicae & Cipendawa/Cipanas/Cianjur & 1157 & $\begin{array}{l}\text { Sweet potato, I. batatas } \\
\text { (1) }\end{array}$ & Convolvulaceae \\
\hline \multirow[t]{16}{*}{6.} & $\begin{array}{l}\text { Rhopalosiphum } \\
\text { maidis }\end{array}$ & Cikarawang/Dramaga/Bogor & 182 & Corn, Z. mays (35) & Poaceae \\
\hline & & & 185 & Corn, Z. mays (71) & Poaceae \\
\hline & & Pasir jambu/Cibinong/Bogor & 190 & Corn, Z. mays (11) & Poaceae \\
\hline & & Situgede/Bogor Barat/Bogor & 194 & Corn, Z. mays (1) & Poaceae \\
\hline & & Cijujug/Cibungbulang/Bogor & 211 & Corn, $Z$. mays (51) & Poaceae \\
\hline & & Cibeureum/Dramaga/Bogor & 225 & Corn, Z. mays (30) & Poaceae \\
\hline & & & & Cassava, M. esculenta (2) & Euphorbiaceae \\
\hline & & Sukaharja/Ciomas/Bogor & 232 & Corn, Z. mays (35) & Poaceae \\
\hline & & Cinangka/Ciampea/Bogor & 262 & Peanut, A. hypogaea (1) & Fabaceae \\
\hline & & Cinangneng/Tenjolaya/Bogor & 300 & Corn, $Z$. mays (11) & Poaceae \\
\hline & & $\begin{array}{l}\text { Bantar Jaya/Bantar kambing/ } \\
\text { Bogor }\end{array}$ & 360 & Corn, Z. mays (3) & Poaceae \\
\hline & & Tajur/Cijeruk/Bogor & 466 & Corn, Z. mays (24) & Poaceae \\
\hline & & Ciletuk/Megamendung/Bogor & 593 & Corn, Z. mays (24) & Poaceae \\
\hline & & Pamijahan/Pamijahan/Bogor & 625 & Corn, Z. mays (3) & Poaceae \\
\hline & & Cinangneng/Tenjolaya/Bogor & 633 & Corn, Z. mays (100) & Poaceae \\
\hline & & Ciherang/Pacet/Cianjur & 1045 & Corn, Z. mays (166) & Poaceae \\
\hline
\end{tabular}


Table 1 (Continuation)

\begin{tabular}{|l|l|l|l|l|l|}
\hline 7. & $\begin{array}{l}\text { Rhopaloshipum } \\
\text { padi }\end{array}$ & Cikarawang/Dramaga/Bogor & 178 & Rice, O. sativa (10) & Poaceae \\
\hline & & Cinangneng/Tenjolaya/Bogor & 287 & Rice, O. sativa (4) & Poaceae \\
\hline & & Katulampa/Bogor Timur/Bogor & 368 & Corn, Z. mays (3) & Poaceae \\
\hline & & Ciletuk/Megamendung/Bogor & 593 & Corn, Z. mays (190) & Poaceae \\
\hline & & Leuwimalang/Cisarua/Bogor & 705 & Wheat, Triticum sp. (3) & Poaceae \\
\hline 8. & Sitobion avenae & Cipendawa/Cipanas/Cianjur & 1157 & Corn, Z. mays (26) & Poaceae \\
\hline 9. & $\begin{array}{l}\text { Tetraneura } \\
\text { nigriabdominalis }\end{array}$ & Cijedil/Cugenang/Cianjur & 643 & Rice, O. sativa (20) & Poaceae \\
\hline
\end{tabular}

${ }^{\mathrm{A}}$ number in parentheses represents the number of individuals found in each host

\subsection{Description and Pictorial Key}

The subfamily Aphidinae has antenna with a process terminal equal or longer than the base segment with cornicle-shaped (Figure 10b), the cauda is shaped like a tongue. The subfamily Eriosomatinae has an antenna with the terminal process shorter than the base (Figure 10f), short-sized cornicle (Figure 10a) [2].

\subsubsection{Subfamily Aphidinae}

Aphis gossypii (Glover) (Figure 1). Tribe Aphidini. The aphid was found to live in colonies of considerable amounts, the adult was light green with small body size was $1.5 \mathrm{~mm}$ (Figure 11w). Among other characters used to identify $A$. gossypii, were having a 6 -segment antenna with a process terminal longer than the base segment, the antenna tubercles do not develop (Figure 1e and 10e), Cornicle-like tubes or oblong-colored dark (Figure 1f and 10t) and blackish femur. This aphid was found on taro, corn, and peanut plants in Tenjolaya, Pamijahan, Cikarawang, Situgede, Cinangka, Ciletuk, Cuijedil, and Rancabungur.

Aphis craccivora (Koch) (Figure 2). Tribe Aphidini. The aphid was clearly visible with a black body color and a slightly rounded body shape with a size of $2.0 \mathrm{~mm}$. These aphids lived in colonies, sometimes they appear to live alone or solitary. Among other characters used to identify A. craccivora, were antenna with the terminal process longer than the base segment, the antenna tubercles weak or not developing, dark cornicle, a black spot in the abdominal dorsal (Figure $11 \mathrm{v}$ ) and dark cauda (Figure $1 \mathrm{~g}$ and $11 \mathrm{t}$ ). The aphid was found only on peanut plants in Cikarawang, Kayumanis, and Cinangka. Ants were not found on this aphid colony.

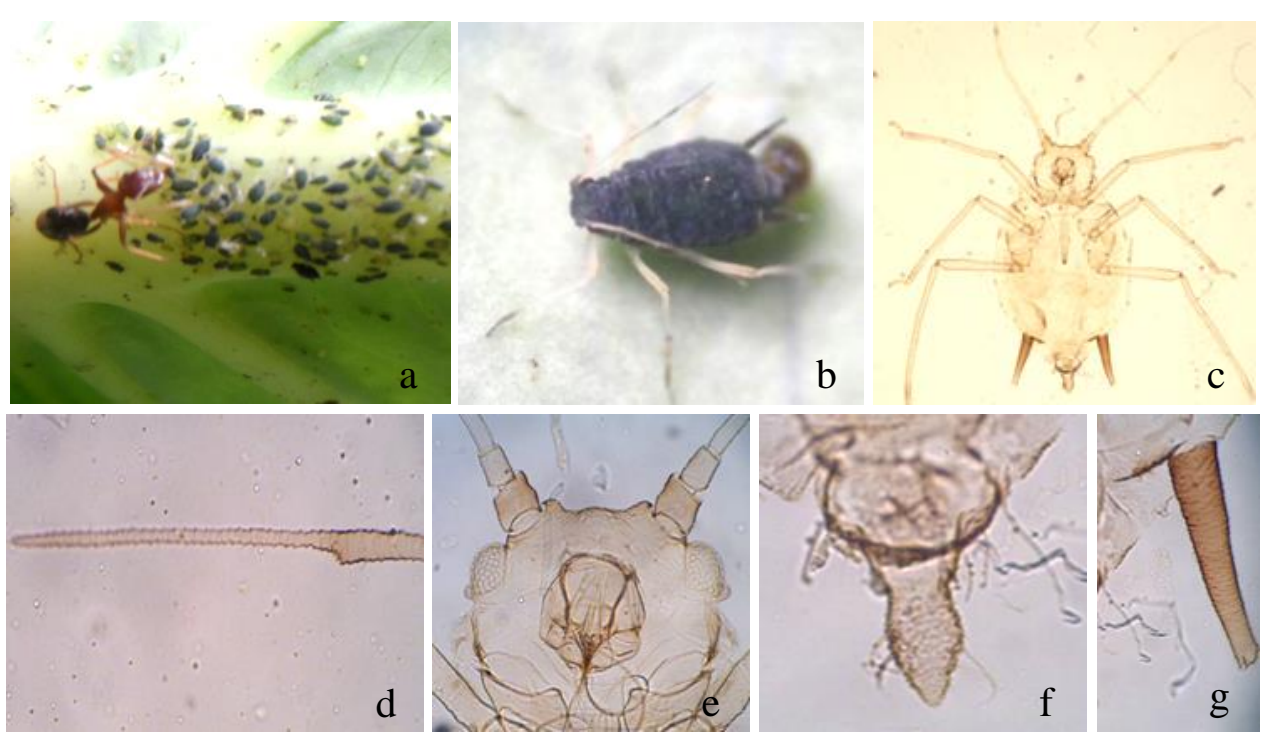

Figure 1 A colony and morphological characters of Aphis gossypii: (a) the aphid colony, (b) the adult aphid, (c) the slide preparation of wingless adult, (d) antenna, (e) tubercle antenna, (f) cornicle, (g) cauda 
body shape was elongated, green in color with size of 2.0 $\mathrm{mm}$ (Figure $4 \mathrm{~b}$ and $11 \mathrm{p}$ ). Among other characters used to identify $R$. maidis, i.e. the antenna tubercles did not develop, have a 6-segment antenna, the process terminal was 2.5 times longer than the base segment (Figure $4 \mathrm{~d}$ and 111), there were fine hair, a dark cornicle and longer than the cauda (Figure 4f-g). The cornicle shape is like a tube, and has dark cauda. The aphid was on corn, peanut, and cassava plants in Cikarawang, Tenjolaya, Pamijahan, Ranca bungur, Cinangka, Pasir Jambu, Cijujug, Situgede, and Pacet.
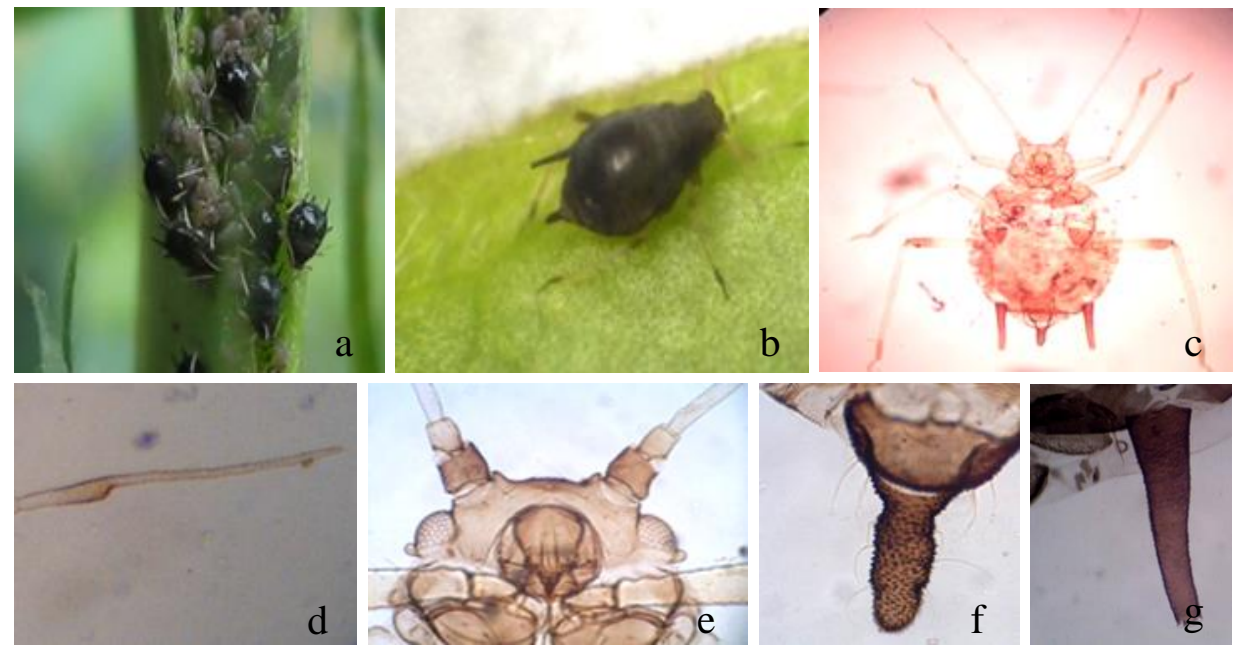

Figure 2 A colony and morphological characters of Aphis craccivora: (a) the aphid colony, (b) the adult aphid, (c) the slide preparation of wingless adult, (d) antenna, (e) tubercle antenna, (f) cornicle, (g) cauda
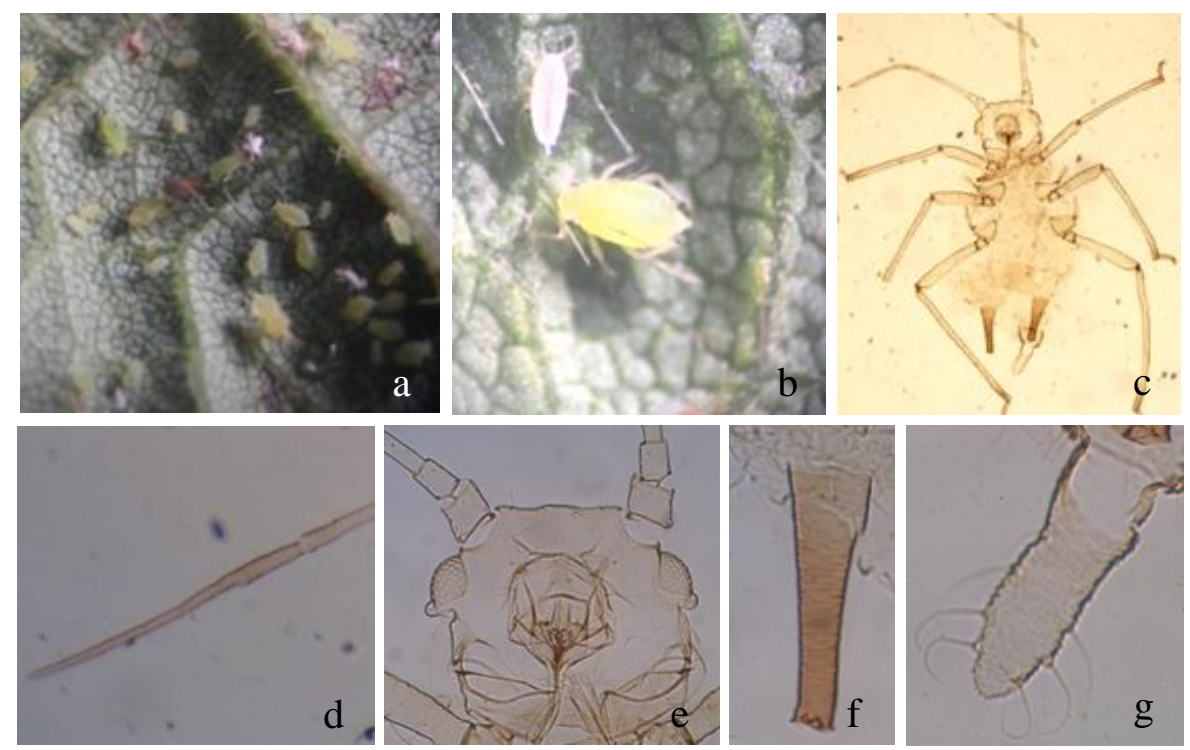

Figure 3 A colony and morphological characters of Aphis glycine: (a) the aphid colony, (b) the adult aphid, (c) the slide preparation of wingless adult, (d) antenna, (e) tubercle antenna, (f) cornicle, $(\mathrm{g})$ cauda 

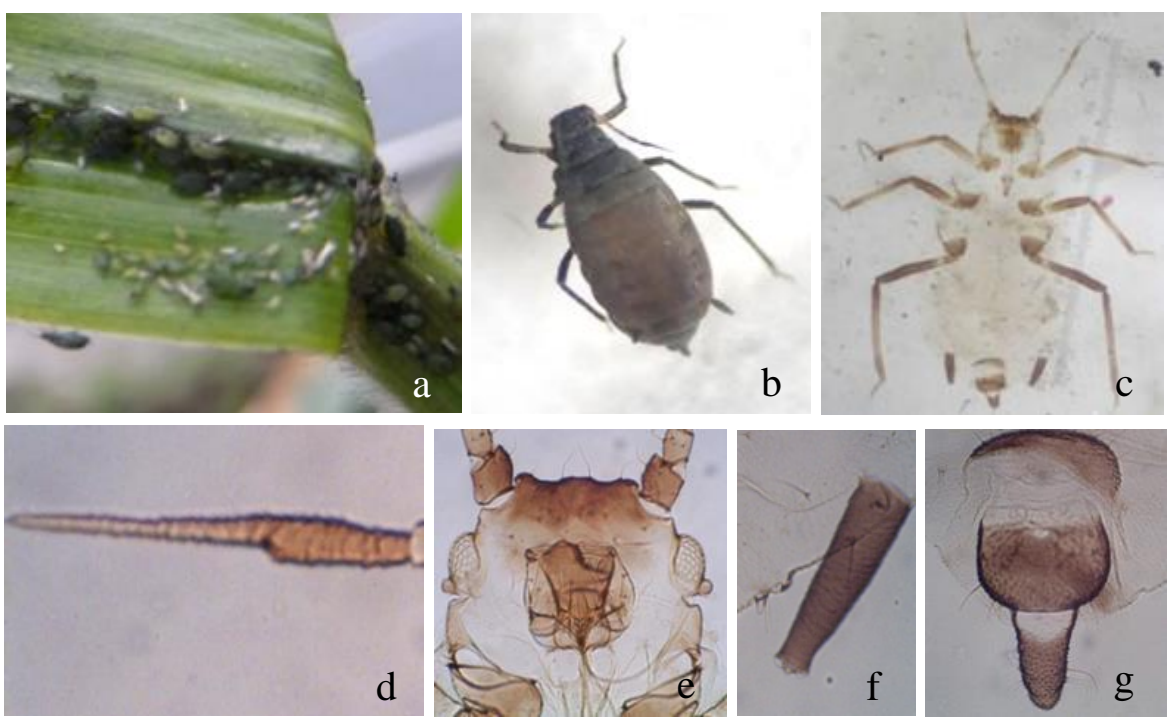

Figure 4 A colony and morphological characters of Rhopalosiphum maidis: (a) the aphid colony, (b) the adult aphid, (c) the slide preparation of wingless adult, (d) antenna, (e) tubercle antenna, (f) cornicle, (g) cauda

Rhopalosiphum padi (L) (Figure 5). Tribe Aphidini. The aphid was brown to greenish brown and black brown. The body shape was somewhat rounded, with size $2.0 \mathrm{~mm}$ (Figure $5 \mathrm{~b}$ and 11q) and lived in colonies beneath the surface of the leaves. The character used to identify $R$. padi included 6 segments of antennae with short hair and the process terminal 3 times longer than the base segment (Figure $2 \mathrm{~m}$ ), there was fine hair on its body, it has the same or longer cornicle than the cauda. The aphid was found on rice, corn, and wheat crops in Cikarawang, Tenjolaya, Katulampa, Cipendawa, Leuwimalang, and Ciletuk.

Sitobion avenae (Fabricius). Tribe Macrosiphini. The aphid was clearly seen by having antennas, cornicle and cauda that are very long compared to other species found. The color of its body was brown with an elongated body shape. Sitobion avenae does not appear to form colonies compare to other species. Among other characters used to identify $S$. avenae, i.e. antenna with a process terminal 5 times longer than the base segment, cornicle-like tubes and a 1.4 longer from cauda and equally dark (Figure $6 f$ and $10 \mathrm{~g}$ ), there was a black mark on the abdomen (Figure 10j). The aphid was found in Leuwimalang on wheat.

Myzus persicae (Sulzer) (Figure 7). Tribe Macrosiphini. M. persicae was greenish yellow, has a body length of about $1.5 \mathrm{~mm}$ (Figure $7 \mathrm{a}$ and 10k), and did not appear to form colonies compare to other species. The characters used to identify $M$. persicae, i.e. antennae had a process terminal 3.5 times longer than the base segment, the antenna tubercles evolved (Figure 7c and 10d), cornicle and pale cauda (Figure 7e-f and 10h). The aphid was found in the Cipendawa on sweet potato.

Hysteroneura setariae (Thomas) (Figure 8). Tribe Aphidini. This aphid was blackish brown with rounded body, body size was about $1.7 \mathrm{~mm}$ (Figure 8a and 11r). Characters used to identify $H$. setariae, i.e. antennae with the terminal process 5 times longer than the base segment (Figure 11n), there were soft small hair on abdominal dorsal, antenna tubercles did not develop well, cauda looks paler than cornicle (Figure 8e-f and 11o) and has dark femur (Figure 8d and 11r). The aphid was found in the Pacet on corn.

\subsubsection{Subfamily Eriosomatinae}

Tetraneura nigriabdominalis (Sasaki) (Figure 9). Tribe Eriosomatini. The aphid lived in colonies on plant roots. The body color was orange to pink, the size was 1.8 $\mathrm{mm}$ with a rounded body shape (Figure 9a and 10i). Tetraneura nigriabdominalis has a shorter antenna with a shorter process terminal than the basic segment (Figure $9 \mathrm{~d}$ and 10c). The antenna tubercles did not develop (Figure 9c and 10f), has a short cornicle (Figure 1e and 10a), tarsi 1 segment, and has a short and hairy rostrum. The aphid was found in Cijedil (Cugenang, Cianjur) on rice root. 

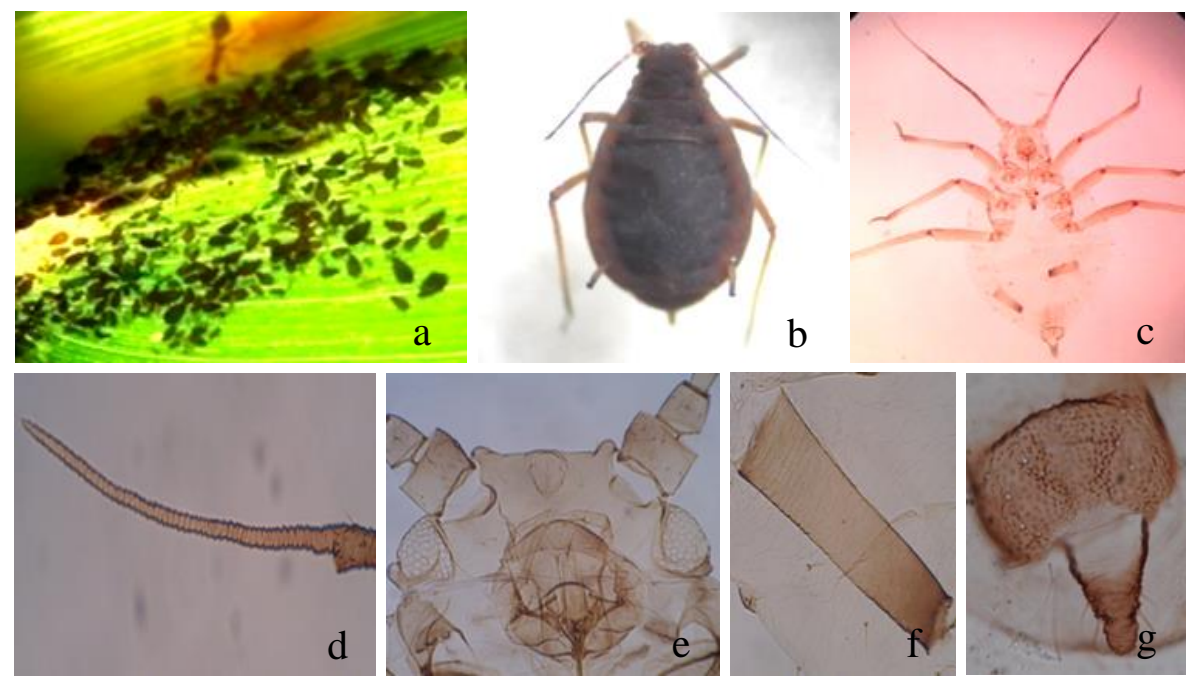

Figure 5 A colony and morphological characters of Rhopalosiphum padi: (a) the aphid colony, (b) the adult aphid, (c) the slide preparation of wingless adult, (d) antenna, (e) tubercle antenna, (f) cornicle, (g) cauda
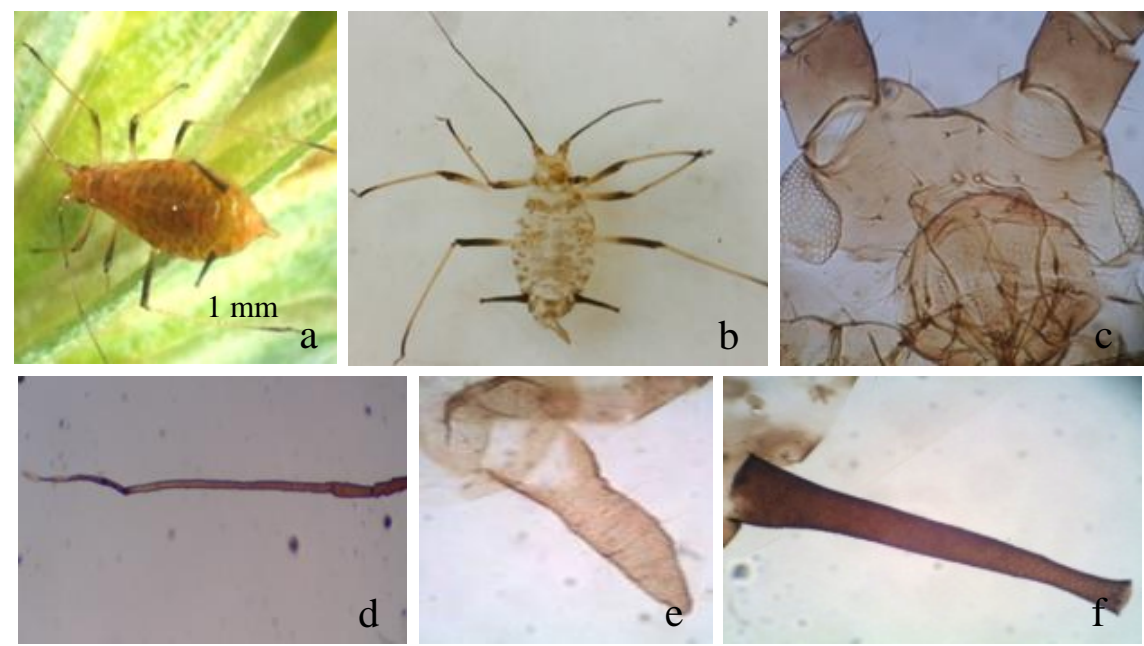

Figure 6 An aphid and morphological characters of Sitobion avenae: (a) the adult aphid, (b) the slide preparation of wingless adult, (c) tubercle antenna, (d) antenna, (e) cornicle, (f) cauda 

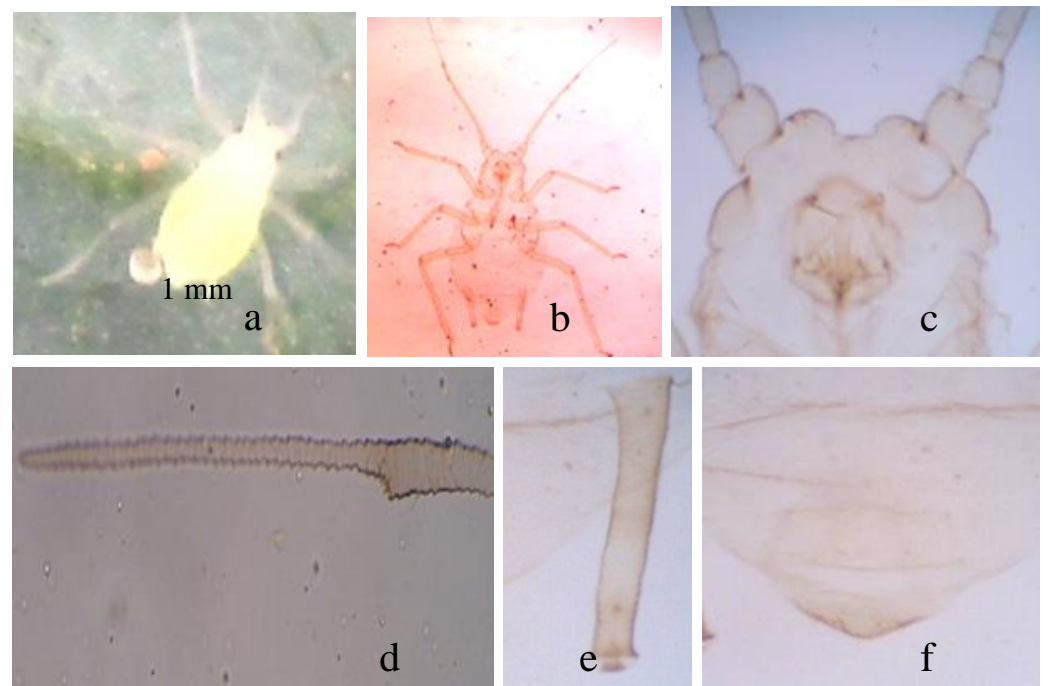

Figure 7 An aphid and morphological characters of Sitobion avenae: (a) the adult aphid, (b) the slide preparation of wingless adult, (c) tubercle antenna, (d) antenna, (e) cornicle, (f) cauda
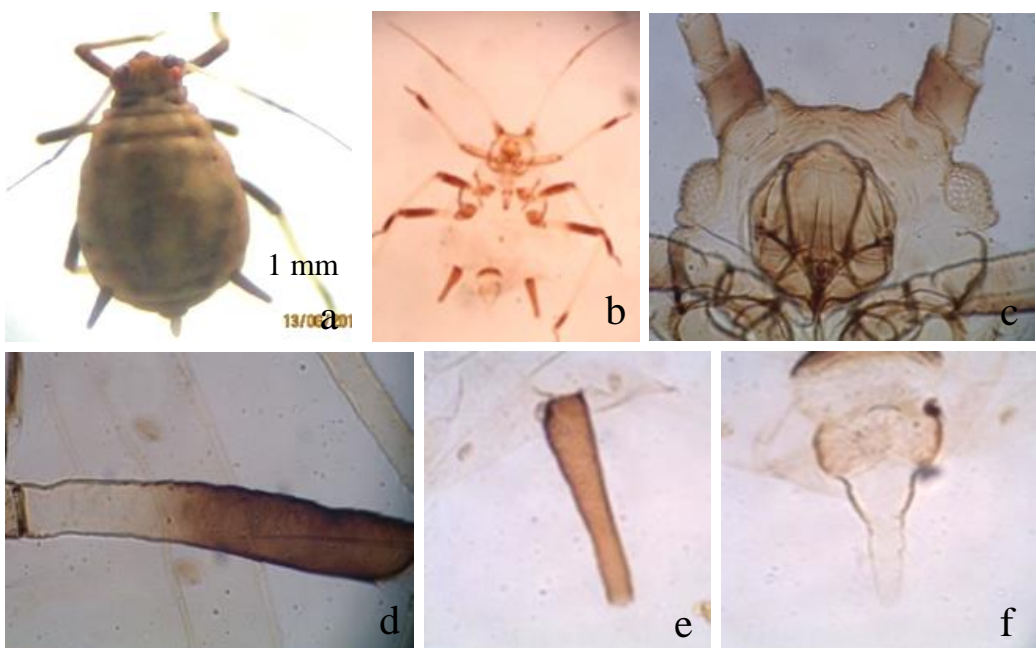

Figure 8 An aphid and morphological characters of Hyteroneura setariae: (a) the adult aphid, (b) the slide preparation of wingless adult, (c) tubercle antenna, (d) a dark femur, (e) cornicle, (f) cauda 

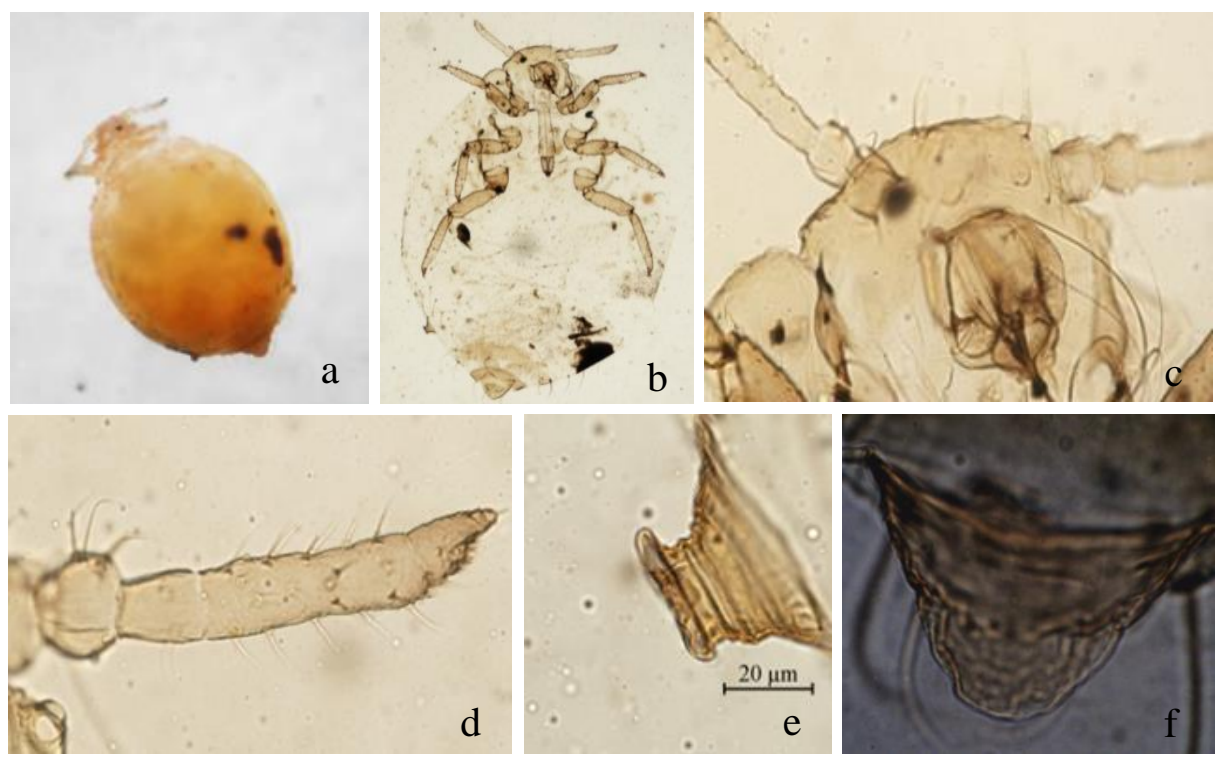

Figure 9 An aphid and morphological characters of Tetraneura nigriabdominalis: (a) the adult aphid, (b) the slide preparation of wingless adul,t (c) tubercle antenna not developed, (d) antenna, (e) short cornicle, (f) cauda 
Adult aphid (Apterous)

a

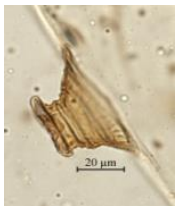

Cornicle pore/cone shaped

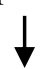

Subfamily

Eriosomatinae;

Tribe Eriosomatini

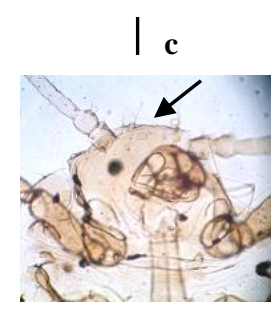

The antenna tubercles do not develop, hairy

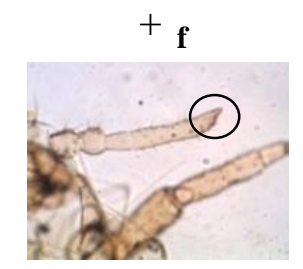

Terminal process is shorter than the base segment

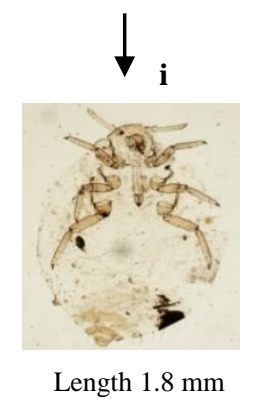

T. nigriabdominalis

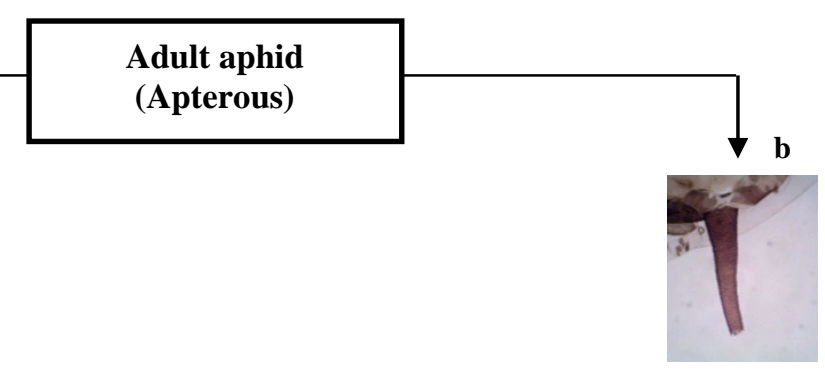

Cornicle tube shaped

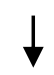

Subfamily

Aphidinae

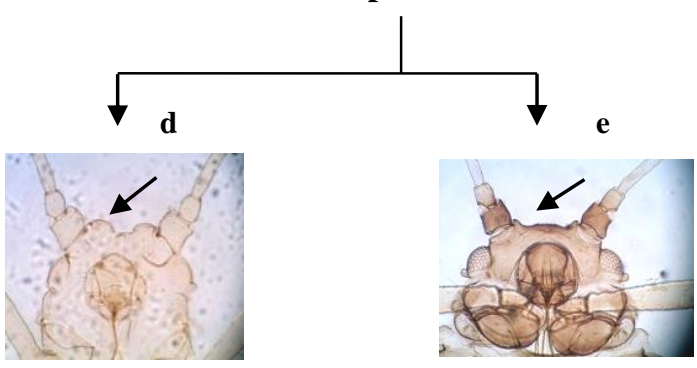

The antenna tubercles developed

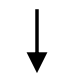

Tribe Macrosiphini

1 Tribe Aphidini

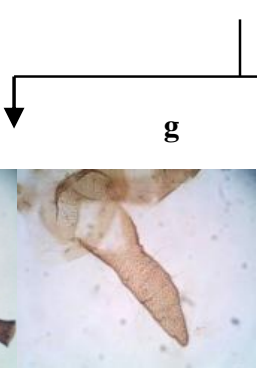

The antenna tubercles do not develop

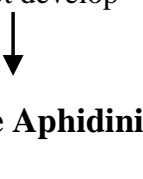

Dark cornicle and cauda
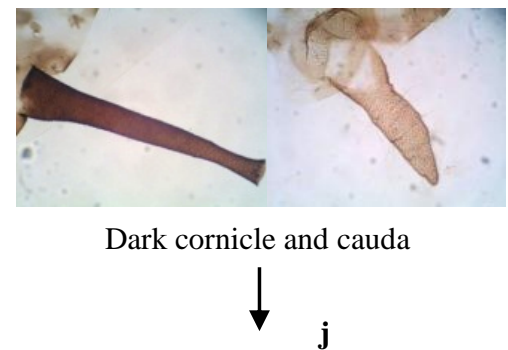
$\mathbf{j}$

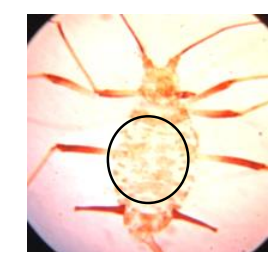

Black mark on the abdomen

Length $2.75 \mathrm{~mm}$

S. avenae h

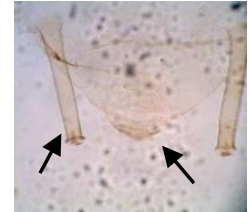

Pale cornicle and cauda

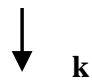

$\mathbf{k}$

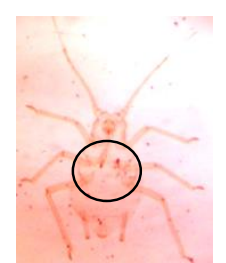

No mark on the abdomen Length $1.5 \mathrm{~mm}$

M. persicae

Figure 10 The pictorial key of aphid species Subfamily Eriosomatinae, Tribe Eriosomatini and Subfamily Aphidinae: Tribe macroshipini collected from food crops in Bogor and Cianjur. 
Terminal process 2.5-3.5 times longer than the base segment

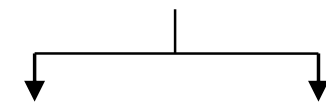

Rhopalosiphum sp. Aphis sp. 2

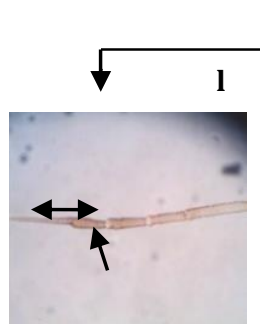

The terminal process 2.5 times longer than the

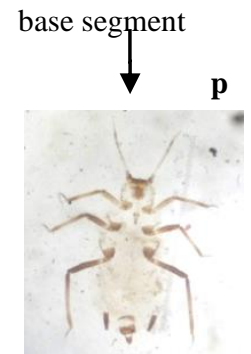

Length $2.0 \mathrm{~mm}$

R. maidis

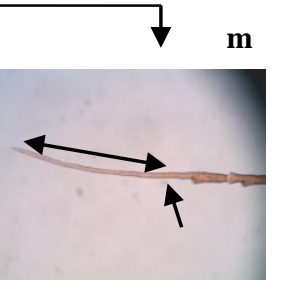

Terminal process 3 times longer than the base segment

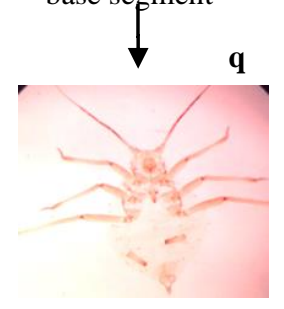

Length $2.0 \mathrm{~mm}$

$$
\text { R. padi }
$$

Terminal process 5 times longer than the base segment

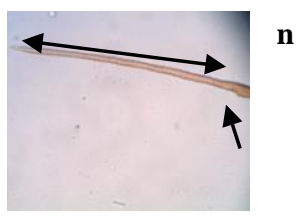

$+$

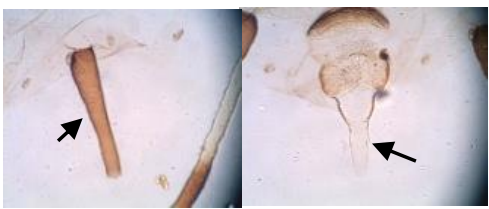

Dark cornicle; Pale cauda

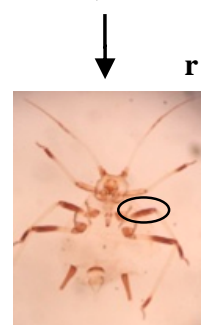

Dark femur Length $1.7 \mathrm{~mm}$

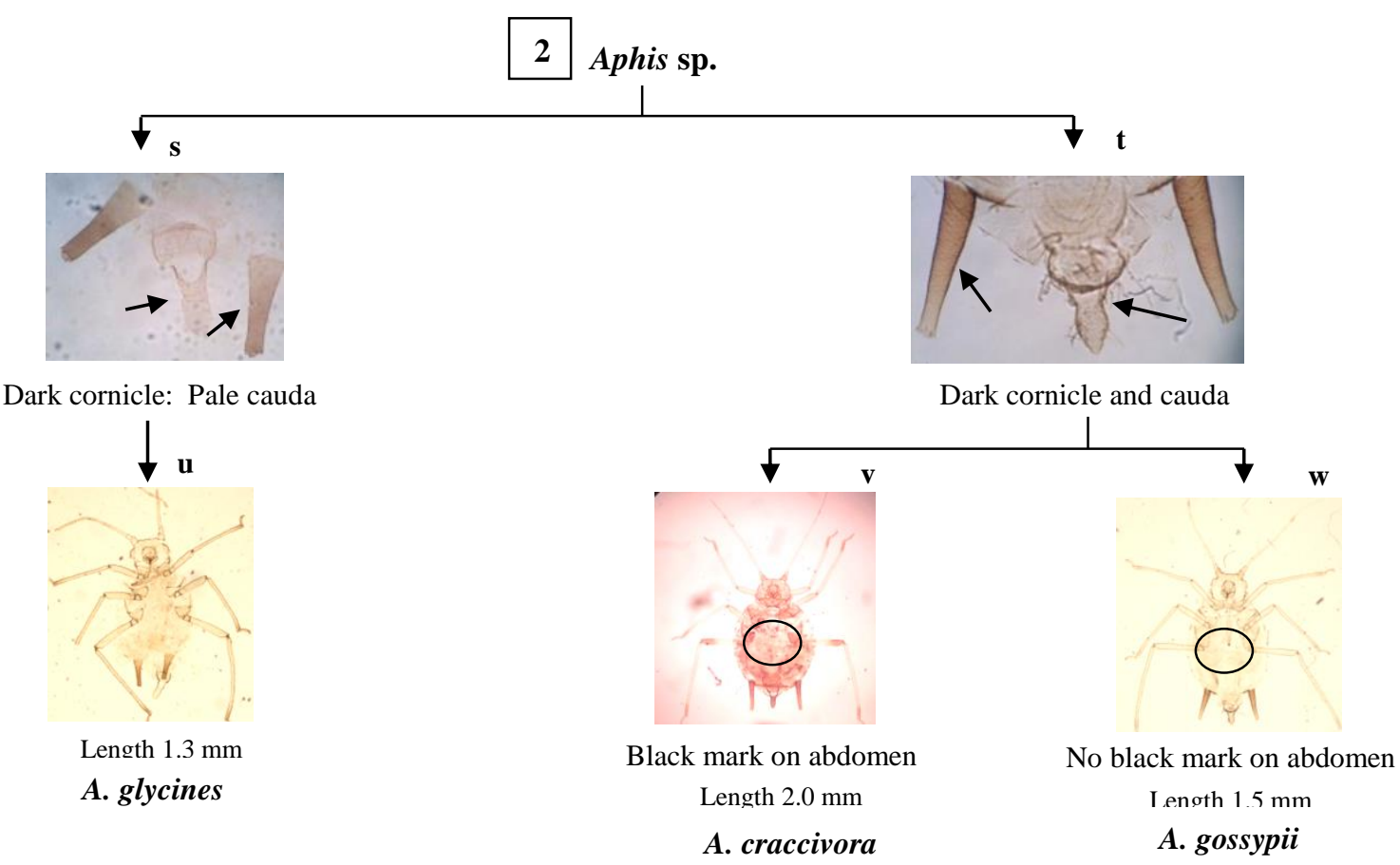

Figure 11 Pictorial key of aphid species (Tribe Aphidini) collected from food crops in Bogor and Cianjur. 
[4] V.D. Goot, Zur Kenntnis Der Blattlause Java's. Contributions's a la faune des Indes neerlandaises. Vol. 1, Fasc. I. Inst. Sci. Buitenzorg, Instituts Scientifiques de Buitenzorg Lands Plantentuin, 1917

Bogor and Cianjur districts. Among of them A. gossypii is the most dominant aphid on the crops. The highest aphid infestation is observed on Poaceae. Among nine aphid species found, seven species have been reported as important plant pests, because as a virus vector in several important plants.

\section{ACKNOWLEDGMENT}

We would like to thank students in the Insect Biosystematics Laboratory and Ibu Iis Aisyah for helping in sample collections and microscope slide preparations.

\section{REFERENCES}

[1] W.L. Morrill, Insect Pests of Small Grains. Bozeman (US): APS Press Montana State University. MILES PW. 1987. Feeding process of Aphidoidea in relation of effects on their food plants. Inside: minks AK, harrewijn P, editor. Aphids: Their Biology, Natural Enemies and Control. Amsterdam (NL): Elsevier, 2A (1995) 321-340

[2] R.L. Blackman, V.F. Eastop, Aphids on the world's Crop; an Identification and Information Guide. $2^{\text {nd }}$ Edition. Chichster (GB): Wiley, 2000

[3] M. Miyazaki, Morphology and systematics. Inside: minks AK, Harrewijn P, editor. Aphids Their Biology, Natural Enemies and Control. Amsterdam: Elsevier, 1987, pp. 4-8.

[5] D. Noordam, Hormaphidinae from Java (homoptera: Aphididae). Zool. Verh. 270 (1991) 1-525

[6] D. Noordam, Greenideinae from Java (homoptera: Aphididae). Zool. Verh. 296 (1994) 1-284

[7] D. Noordam, Aphid of Java part V: Aphidini (Homoptera: Aphididae). Zool. Verh. 346 (2004) 1225

[8] P.W. Miles, Feeding process of Aphidoidea in relation of effects on their food plants in Minks AK, Harrewijn P, editor. Aphids: Their Biology, Natural Enemies and Control. Amsterd am (NL): Elsevier, 2A (1987) 321340

[9] C. Irsan, S. Sosromarsono, D. Buchori, H. Triwidodo, Kutudaun (Homoptera: Aphidoidea) yang ditemukan hidup pada Solanaceae di Jawa Barat. Bul HPT. 10(2) (1998) 1-4

[10] AphID, Identification Guide for Cosmopolitan and polyphagous aphid species, 2013 [Internet]. [Downloaded: 2013 April 20-21] http: //aphid. aphidnet.org /index.php

[11] L.P. Pedigo, M.E. Rice, Entomology and Pest Management. $5^{\text {th }}$ ed. Upper Saddle River, Pearson Education, 2006 